\title{
Natural Radioactivity Measurements and Radiation Dose Estimation in Some Sedimentary Rock Samples in Turkey
}

\author{
I. Akkurt ${ }^{1}$ and K. Günoğlu ${ }^{2}$ \\ ${ }^{1}$ Suleyman Demirel University, Fen-Edebiyat Fakultesi Fizik Bölümü, 32260 Isparta, Turkey \\ ${ }^{2}$ Technical Sciences Vocational School, Suleyman Demirel University, 32260 Isparta, Turkey \\ Correspondence should be addressed to I. Akkurt; iskenderakkurt@sdu.edu.tr
}

Received 29 September 2013; Revised 19 December 2013; Accepted 29 December 2013; Published 2 April 2014

Academic Editor: Keith E. Holbert

Copyright ( 2014 I. Akkurt and K. Günoğlu. This is an open access article distributed under the Creative Commons Attribution License, which permits unrestricted use, distribution, and reproduction in any medium, provided the original work is properly cited.

\begin{abstract}
The natural radioactivity existed since creation of the universe due to the long life time of some radionuclides. This natural radioactivity is caused by $\gamma$-radiation originating from the uranium and thorium series and ${ }^{40} \mathrm{~K}$. In this study, the gamma radiation has been measured to determine natural radioactivity of ${ }^{238} \mathrm{U},{ }^{232} \mathrm{Th}$, and ${ }^{40} \mathrm{~K}$ in collected sedimentary rock samples in different places of Turkey. The measurements have been performed using $\gamma$-ray spectrometer containing $\mathrm{NaI}(\mathrm{Tl})$ detector and multichannel analyser (MCA). Absorbed dose rate $(D)$, annual effective dose (AED), radium equivalent activities $\left(\mathrm{Ra}_{\mathrm{eq}}\right)$, external hazard index $\left(H_{\mathrm{ex}}\right)$, and internal hazard index $\left(H_{\mathrm{in}}\right)$ associated with the natural radionuclide were calculated to assess the radiation hazard of the natural radioactivity in the sedimentary rock samples. The average values of absorbed dose rate in air $(D)$, annual effective dose (AED), radium equivalent activity $\left(\mathrm{Ra}_{\mathrm{eq}}\right)$, external hazard index $\left(H_{\mathrm{ex}}\right)$, and internal hazard index $\left(H_{\mathrm{in}}\right)$ were calculated and these were $45.425 \mathrm{nGy} / \mathrm{h}, 0.056 \mathrm{mSv} / \mathrm{y}, 99.014 \mathrm{~Bq} / \mathrm{kg}, 0.267$, and 0.361 , respectively.
\end{abstract}

\section{Introduction}

The natural radioactivity existed since creation of the universe due to the long life time of radionuclide. This natural radioactivity is caused by $\gamma$-radiation originating from the uranium and thorium series and ${ }^{40} \mathrm{~K}$. Natural radioactivity arising from natural sources is the main contribution to the annual dose received by the world's population, exposure resulting from radionuclides inherent in the earth's crust and from cosmic rays. The terrestrial radionuclides are ubiquitous, belonging to the ${ }^{238} \mathrm{U}$ and ${ }^{232} \mathrm{Th}$ series and their decay products as well as single decay radionuclides, particularly

${ }^{40} \mathrm{~K}$. Gamma radiation emitted from such naturally occurring radionuclides in all ground formations represents the main external exposure to human body [1]. The knowledge of concentrations and distributions of the radionuclides are of interest since it provides useful information in the monitoring of environmental radioactivity. Natural environmental radioactivity and the associated external exposure due to gamma radiation depend primarily on the geological and geographical conditions and appear at different levels in the soils and rocks of each region in the world [2-4].

In this study, the natural radioactivity concentrations of ${ }^{40} \mathrm{~K},{ }^{238} \mathrm{U}\left({ }^{226} \mathrm{Ra}\right)$, and ${ }^{232} \mathrm{Th}$ in some sedimentary rock samples collected in different regions of Turkey have been investigated. The results were used to assess the radiological hazard associated with the absorbed gamma dose rate in air $(D)$, the annual effective dose rate, radium equivalent activities $\left(\mathrm{Ra}_{\mathrm{eq}}\right)$, external hazard index $\left(H_{\mathrm{ex}}\right)$, and internal hazard index $\left(H_{\text {in }}\right)$ from gamma radiation.

\section{Material and Methods}

In this study 19 different types of sedimentary rocks have been collected in different regions of Turkey. In Figure 1 the locations of Turkey in which samples were collected have been shown. After collection of samples, they were crushed and grinded to get proper grain size 100 mesh sieve. Then, samples were dried until $100^{\circ} \mathrm{C}$ in an oven for about $24 \mathrm{~h}$. The dried samples have been filled in a cup which is sealed tightly 


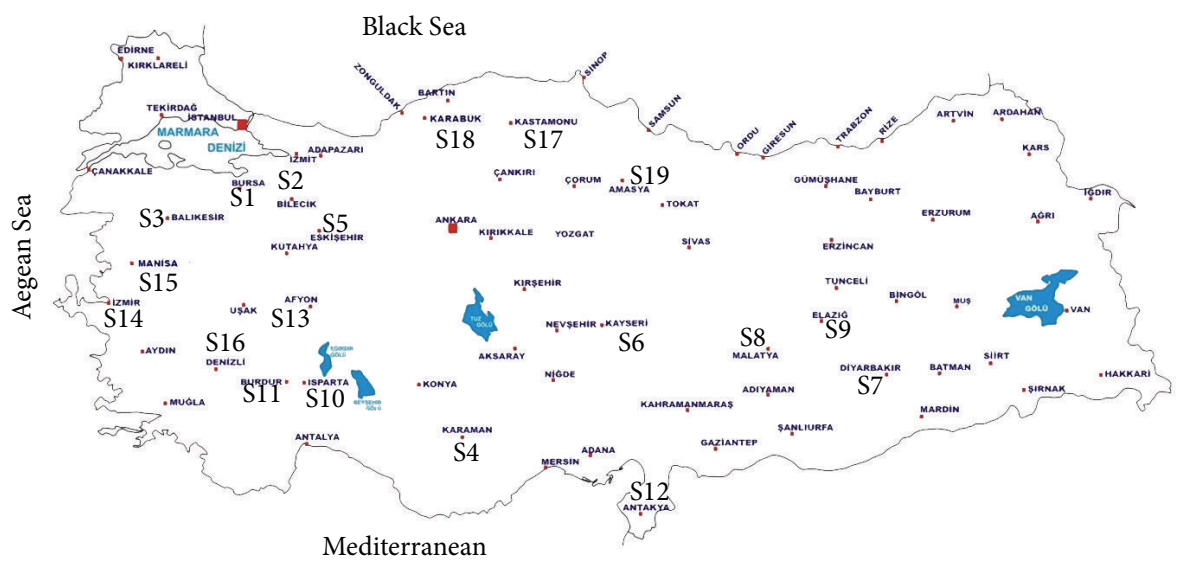

FIgURE 1: The location of the sampling sites of the sedimentary rocks in Turkey.

with a thick tape around its neck to limit any gas escape from it, and it was stored for four weeks to get secular equilibrium to be achieved between ${ }^{238} \mathrm{U}$ and its progeny [5].

The radioactivity of ${ }^{226} \mathrm{Ra},{ }^{232} \mathrm{Th}$, and ${ }^{40} \mathrm{~K}$ in the sedimentary rock samples was determined using a gamma-ray spectrometry [6] consisting of a $3^{\prime \prime} \times 3^{\prime \prime} \mathrm{NaI}(\mathrm{Tl})$ detector connected to a 16384-channel multichannel analyser (MCA). Before measurement the system should be calibrated. This is done using ${ }^{137} \mathrm{Cs}$ and ${ }^{60} \mathrm{Co}$ radioactive sources, which produce $\gamma$-ray energy of 662,1173 , and $1332 \mathrm{keV}$, respectively. The $\gamma$-ray spectrum obtained from the mentioned source and related fit has been displayed in Figure 2.

The spectrum is analyzed using the MAESTRO32 obtained from ORTEC. The measurement was based on recording natural radioactivity quantities of three natural long-live elements: ${ }^{226} \mathrm{Ra},{ }^{232} \mathrm{Th}$, and ${ }^{40} \mathrm{~K}$ which are considered the photopeaks at 1760,2610 , and $1461 \mathrm{keV}$, respectively, in the natural $\gamma$-ray spectrum [5]. The efficiency calibration of the detector system was measured [7] and the results have been used in this work.

The activities for the natural radionuclides were calculated using the following relation [8]:

$$
A(\mathrm{~Bq} / \mathrm{kg})=\frac{N}{\varepsilon \cdot \gamma \cdot t \cdot m}
$$

where $A$ is the activity of the radionuclide in $\mathrm{Bq} / \mathrm{kg}$ and $N$ is the net peak area under the most prominent photo peaks calculated by subtracting the respective count rate from the background spectrum obtained for the same counting time. The net count rate in the measurement is calculated from the background subtracted area of prominent gamma-ray peaks. $\varepsilon$ is the detector efficiency of the specific gamma-ray, $\gamma$ the absolute transition probability of gamma decay, $t$ the counting time (s) which is $72000 \mathrm{~s}$, and $m$ the mass of the sample (kg).

\section{Results and Discussion}

The activity concentrations of natural radionuclides $\left({ }^{40} \mathrm{~K}\right.$, ${ }^{238} \mathrm{U}\left({ }^{226} \mathrm{Ra}\right)$, and $\left.{ }^{232} \mathrm{Th}\right)$ in the sedimentary rocks collected

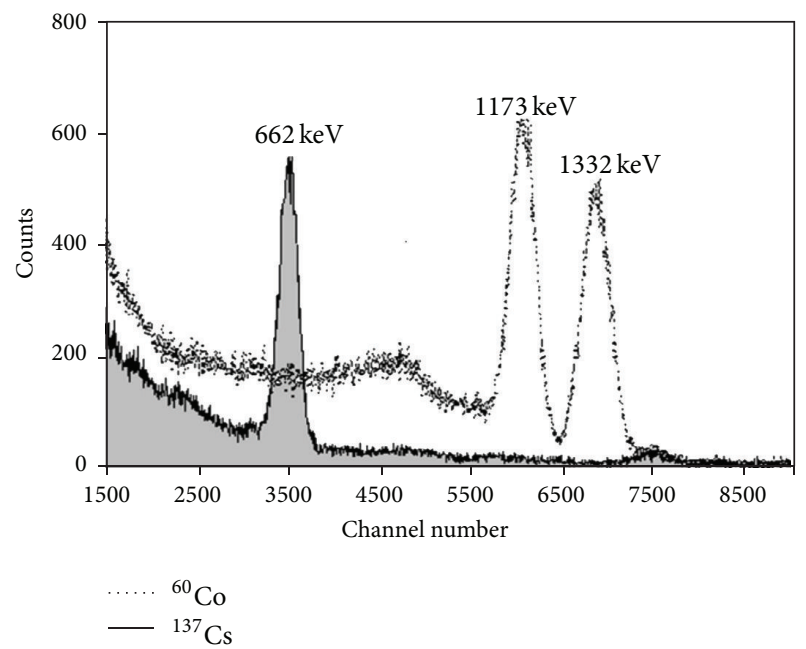

(a)

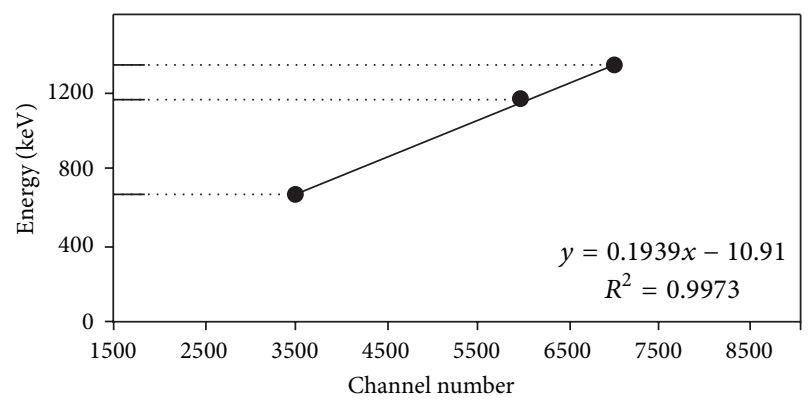

(b)

Figure 2: Calibration spectrum obtained for ${ }^{137} \mathrm{Cs}$ and ${ }^{60} \mathrm{Co}$ source (a) and related fit (b).

in Turkey are presented in Table 1. As shown in Table 1, the activity concentrations of sedimentary rock samples have ranged from 143.97 to $452.34 \mathrm{~Bq} / \mathrm{kg}$ for ${ }^{40} \mathrm{~K}$, from 12.01 to $48.95 \mathrm{~Bq} / \mathrm{kg}$ for ${ }^{226} \mathrm{Ra}$, and from 8.2 to $53.27 \mathrm{~Bq} / \mathrm{kg}$ for ${ }^{232} \mathrm{Th}$. The obtained results have been displayed in Figure 3.

The highest concentrations for all natural radionuclides were detected in the sample 13 (S13) which was collected from 
TABLE 1: The activity concentration of ${ }^{40} \mathrm{~K},{ }^{226} \mathrm{Ra}$, and ${ }^{232} \mathrm{Th}$ (in Bq/kg) of sedimentary rock samples.

\begin{tabular}{|c|c|c|c|c|}
\hline \multirow{2}{*}{ Sample } & \multirow{2}{*}{ Region } & \multicolumn{3}{|c|}{ Activity concentration (Bq/kg) } \\
\hline & & ${ }^{40} \mathrm{~K}$ & ${ }^{226} \mathrm{Ra}$ & ${ }^{232} \mathrm{Th}$ \\
\hline S1 & Bursa & $253.85 \pm 12.69$ & $36.23 \pm 1.81$ & $25.05 \pm 1.25$ \\
\hline S2 & Bilecik & $189.52 \pm 9.48$ & $25.34 \pm 1.27$ & $18.77 \pm 0.94$ \\
\hline S3 & Balıkesir & $197.17 \pm 9.86$ & $34.04 \pm 1.70$ & $27.02 \pm 1.35$ \\
\hline S4 & Karaman & $143.97 \pm 7.20$ & $48.00 \pm 2.40$ & $39.18 \pm 1.96$ \\
\hline S5 & Eskişehir & $284.26 \pm 14.21$ & $28.83 \pm 1.44$ & $8.20 \pm 0.41$ \\
\hline S6 & Kayseri & $247.30 \pm 12.36$ & $17.55 \pm 0.88$ & $33.49 \pm 1.67$ \\
\hline S7 & Diyarbakır & $179.65 \pm 8.98$ & $27.83 \pm 1.39$ & $18.55 \pm 0.93$ \\
\hline S8 & Malatya & $158.74 \pm 7.94$ & $44.48 \pm 2.22$ & $34.46 \pm 1.72$ \\
\hline S9 & Elazı̆̆ & $264.01 \pm 13.20$ & $12.01 \pm 0.60$ & $45.93 \pm 2.30$ \\
\hline S10 & Isparta & $183.55 \pm 9.18$ & $35.67 \pm 1.78$ & $22.77 \pm 1.14$ \\
\hline S11 & Burdur & $346.12 \pm 17.31$ & $32.83 \pm 1.64$ & $37.52 \pm 1.88$ \\
\hline S12 & Hatay & $180.19 \pm 9.01$ & $37.43 \pm 1.87$ & $31.86 \pm 1.59$ \\
\hline S13 & Afyon & $452.34 \pm 22.62$ & $48.95 \pm 2.45$ & $53.27 \pm 2.66$ \\
\hline S14 & İzmir & $168.57 \pm 8.43$ & $22.57 \pm 1.13$ & $24.39 \pm 1.22$ \\
\hline S15 & Manisa & $180.19 \pm 9.01$ & $37.43 \pm 1.87$ & $31.86 \pm 1.59$ \\
\hline S16 & Denizli & $260.41 \pm 13.02$ & $41.86 \pm 2.09$ & $36.73 \pm 1.84$ \\
\hline S17 & Kastamonu & $376.39 \pm 18.82$ & $48.62 \pm 2.43$ & $42.18 \pm 2.11$ \\
\hline S18 & Karabük & $156.98 \pm 7.85$ & $30.90 \pm 1.55$ & $27.86 \pm 1.39$ \\
\hline S19 & Amasya & $395.28 \pm 19.76$ & $47.94 \pm 2.40$ & $47.29 \pm 2.36$ \\
\hline & & 500.00 & 50.00 & 50.00 \\
\hline
\end{tabular}

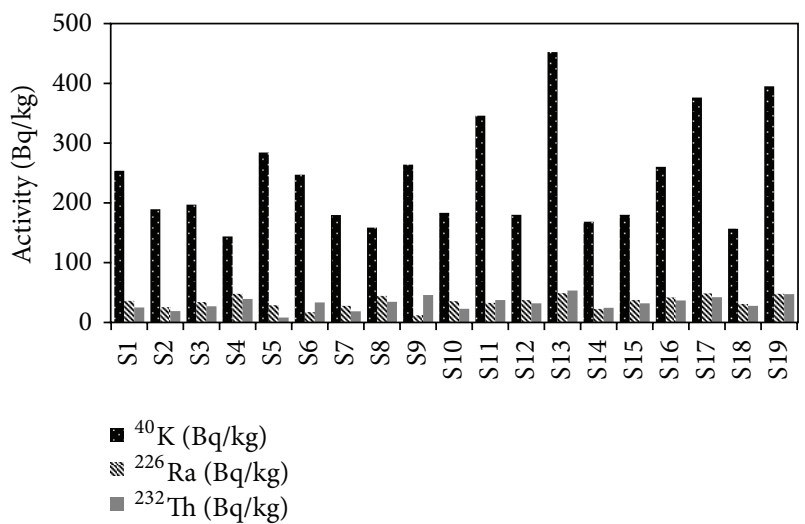

FIgURE 3: The activity concentration of ${ }^{40} \mathrm{~K},{ }^{226} \mathrm{Ra}$, and ${ }^{232} \mathrm{Th}$ for all samples.

Afyon region. The worldwide average concentrations have been reported as $50 \mathrm{~Bq} / \mathrm{kg}$ for ${ }^{226} \mathrm{Ra}$ and ${ }^{232} \mathrm{Th}$ concentrations and $500 \mathrm{~Bq} / \mathrm{kg}$ for ${ }^{40} \mathrm{~K}$ in the UNSCEAR, United Nations Scientific Committee on the Effects of Atomic Radiation [912]. It was found that obtained results for ${ }^{40} \mathrm{~K}$ and ${ }^{226} \mathrm{Ra}$ concentrations are lower than the worldwide average values. For ${ }^{232} \mathrm{Th}$ concentration, S13 is higher than the worldwide average values.

The ${ }^{40} \mathrm{~K},{ }^{226} \mathrm{Ra}$, and ${ }^{232} \mathrm{Th}$ activity concentrations are used for estimation of the absorbed dose rate $(D)$, the annual effective dose rates (AED), the radium equivalent activity $\left(\mathrm{Ra}_{\mathrm{eq}}\right)$, and the index of external and internal radiation hazard $\left(H_{\mathrm{ex}}\right.$ and $\left.H_{\text {in }}\right)$.

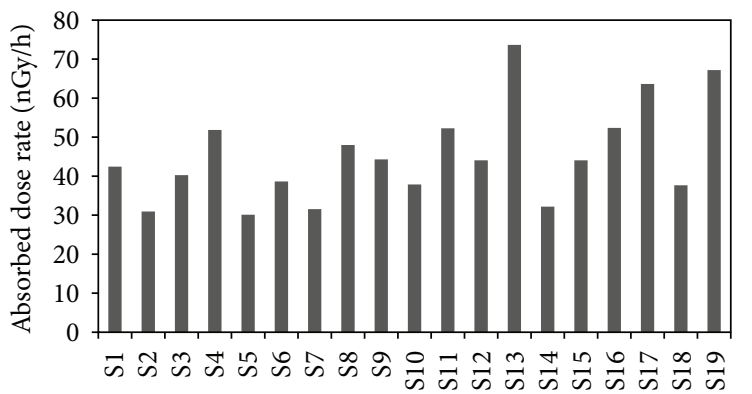

Figure 4: Gamma absorbed dose rate at $1 \mathrm{~m}$ above ground for all samples.

The absorbed dose rate $(D)$ in air at $1 \mathrm{~m}$ above the ground is calculated to provide a characteristic of the external terrestrial $\gamma$-ray $[5,11,13]$ :

$$
D\left(\mathrm{nGy} \cdot \mathrm{h}^{-1}\right)=0.462 A_{\mathrm{Ra}}+0.604 A_{\mathrm{Th}}+0.0417 A_{\mathrm{K}},
$$

where $A_{\mathrm{Ra}}, A_{\mathrm{Th}}$, and $A_{\mathrm{K}}$ are activity concentrations of ${ }^{226} \mathrm{Ra}$, ${ }^{232} \mathrm{Th}$, and ${ }^{40} \mathrm{~K}$ in $\mathrm{Bq} / \mathrm{kg}$, respectively. The absorbed dose rate ranged from 30.13 to $73.65 \mathrm{nGy} \cdot \mathrm{h}^{-1}$. The absorbed dose rate is displayed in Figure 4. The global average value of absorbed dose rate is $55 \mathrm{nGy} \cdot \mathrm{h}^{-1}$ [11].

The annual effective dose rates (AED) should be obtained to test the health effect of those absorbed dose rates. In order to estimate the annual effective doses, one has to take into account to conversion coefficient from absorbed dose in air to effective and the outdoor occupancy factor. In the 
UNSCEAR [11] reports, a value of 0.7 Sv/Gy was used for the conversion coefficient from absorbed dose in air to effective dose received by adults and 0.2 for the outdoor occupancy factor. The annual effective dose equivalent was calculated from the following equation:

$$
\begin{aligned}
\operatorname{AED}\left(\mathrm{mSv} \cdot \mathrm{y}^{-1}\right)= & D\left(\mathrm{nGy} \cdot \mathrm{h}^{-1}\right) \times 8760(\mathrm{~h}) \\
& \times 0.2 \times 0.7(\mathrm{~Sv} / \mathrm{Gy}) \times 10^{-6} .
\end{aligned}
$$

The annual effective dose rate values varied from 0.037 to $0.09 \mathrm{mSv} \cdot \mathrm{y}^{-1}$. The AED results have been displayed in Figure 5. The average AED from the terrestrial radionuclides is $0.46 \mathrm{mSv} \cdot \mathrm{y}^{-1}$ in areas with the normal background radiation [11].

Distribution of ${ }^{40} \mathrm{~K},{ }^{226} \mathrm{Ra}$, and ${ }^{232} \mathrm{Th}$ was not uniform in sedimentary rock samples. Uniformity with respect to exposure to radiation was defined in terms of radium equivalent activity $\left(\mathrm{Ra}_{\mathrm{eq}}\right)$ in $\mathrm{Bq} / \mathrm{kg}$ to compare the specific activity of materials containing different amounts of ${ }^{40} \mathrm{~K},{ }^{226} \mathrm{Ra}$, and ${ }^{232} \mathrm{Th}$. The radium equivalent activity was calculated as follows [14]:

$$
\mathrm{Ra}_{\mathrm{eq}}=A_{\mathrm{Ra}}+1.43 A_{\mathrm{Th}}+0.077 A_{\mathrm{K}},
$$

where $A_{\mathrm{Ra}}, A_{\mathrm{Th}}$, and $A_{\mathrm{K}}$ are the activity concentration of ${ }^{226} \mathrm{Ra},{ }^{232} \mathrm{Th}$, and ${ }^{40} \mathrm{~K}$ in $\mathrm{Bq} / \mathrm{kg}$, respectively. $\mathrm{Ra}_{\mathrm{eq}}$ is estimated for the collected samples and is displayed in Figure 6. The values of $\mathrm{Ra}_{\mathrm{eq}}$ varied from 62.44 to $159.15 \mathrm{~Bq} / \mathrm{kg}$. The recommended maximum value for $\mathrm{Ra}_{\mathrm{eq}}$ is $370 \mathrm{~Bq} / \mathrm{kg}$ [14].

The external hazard index $\left(H_{\mathrm{ex}}\right)$ and internal hazard index $\left(H_{\text {in }}\right)$ are calculated from the equations [14]

$$
\begin{aligned}
& H_{\mathrm{ex}}=\frac{A_{\mathrm{Ra}}}{370}+\frac{A_{\mathrm{Th}}}{259}+\frac{A_{\mathrm{K}}}{4810} \leq 1, \\
& H_{\mathrm{in}}=\frac{A_{\mathrm{Ra}}}{185}+\frac{A_{\mathrm{Th}}}{259}+\frac{A_{\mathrm{K}}}{4810} \leq 1,
\end{aligned}
$$

where $A_{\mathrm{Ra}}, A_{\mathrm{Th}}$, and $A_{\mathrm{K}}$ are activity concentrations of ${ }^{226} \mathrm{Ra}$, ${ }^{232} \mathrm{Th}$, and ${ }^{40} \mathrm{~K}$ in $\mathrm{Bq} / \mathrm{kg}$, respectively. The values of internal and external radiation hazard index must be less than unity for radiation hazard to be negligible.

The value of $H_{\mathrm{ex}}$ must be less than unity, which corresponds to the upper limit of $\mathrm{Ra}_{\text {eq }}(370 \mathrm{~Bq} / \mathrm{kg})$, in order to keep the radiation hazard under limit. The results have been displayed in Figure 7.

Also, all index results have been displayed in Table 2. It can be seen that the obtained values of absorbed dose rate for sedimentary rock samples except those collected from Afyon (S13), Kastamonu (S17), and Amasya (S19) are lower than the global average value of absorbed dose rate, which is $55 \mathrm{nGy} \cdot \mathrm{h}^{-1}$. For the annual effective dose, it is clear that none of the results are higher than the UNSCEAR limit, where the average AED from the terrestrial radionuclides is $0.46 \mathrm{mSv} \cdot \mathrm{y}^{-1}$ in areas with the normal background radiation. The estimated values of $\mathrm{Ra}_{\mathrm{eq}}$ in the present work are lower than the recommended maximum value of $370 \mathrm{~Bq} / \mathrm{kg}$. For internal and external radiation hazard index, it can be seen that all measured results are lower than the upper limit of unity.

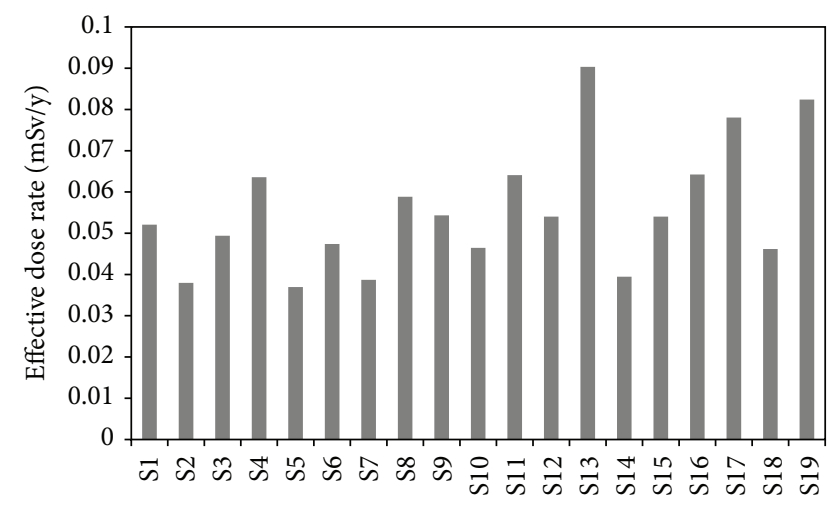

FIGURE 5: Effective dose rate for all samples.

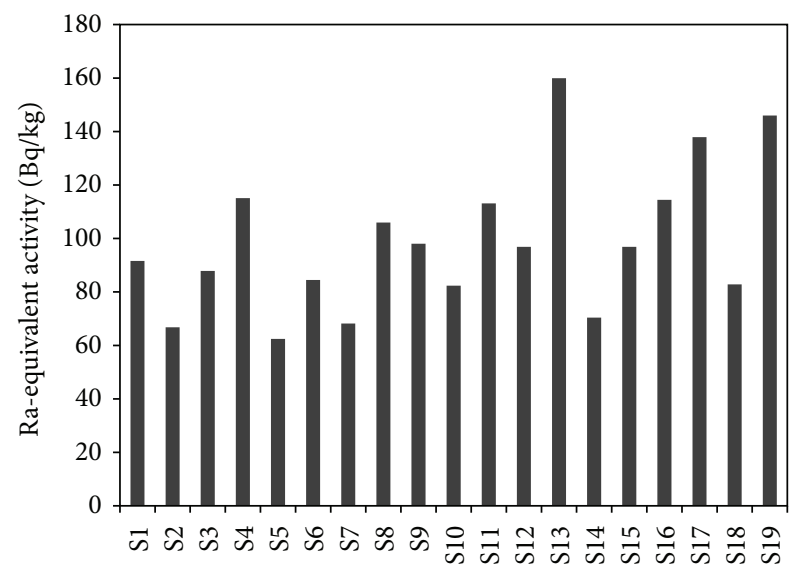

FIgURE 6: Radium equivalent activity for all samples.

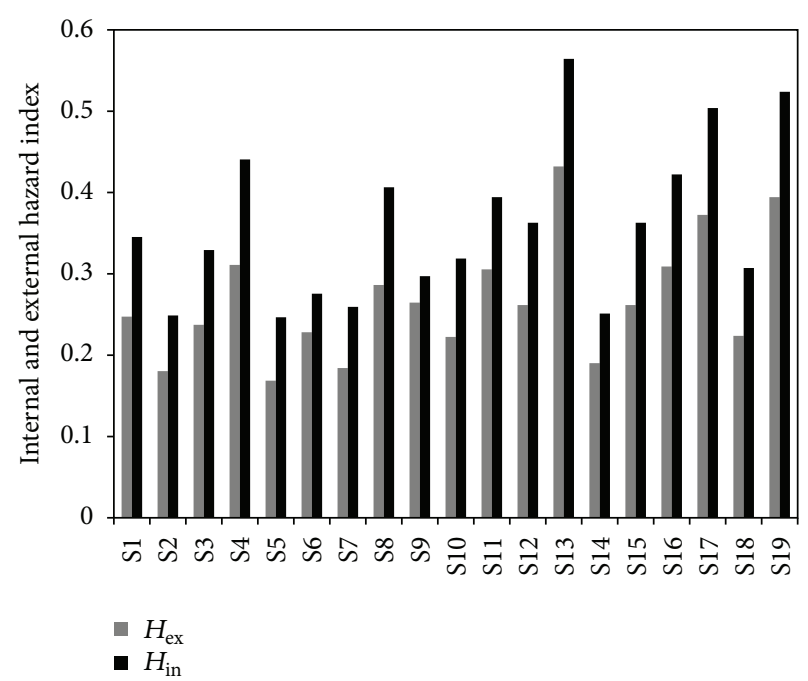

FiguRE 7: External and internal hazard index for all samples.

\section{Conclusion}

The level of natural radioactivity in sedimentary rock samples collected from different regions of Turkey was evaluated using gamma-ray spectrometry. The mean activity concentrations of ${ }^{40} \mathrm{~K},{ }^{226} \mathrm{Ra}$, and ${ }^{232} \mathrm{Th}$ were 243.08, 34.66, 
TABLE 2: Results of the absorbed dose rate $(D)$, the annual effective dose rates (AED), the radium equivalent activity (Ra $\mathrm{eq})$, and the index of external and internal radiation hazard $\left(H_{\mathrm{ex}}, H_{\mathrm{in}}\right)$.

\begin{tabular}{|c|c|c|c|c|c|c|c|}
\hline \multirow{2}{*}{ Sample } & \multirow{2}{*}{ Region } & \multicolumn{6}{|c|}{ Index } \\
\hline & & $D(\mathrm{nGy} / \mathrm{h})$ & AED (mSv/y) & $\mathrm{Ra}_{\mathrm{eq}}(\mathrm{Bq} / \mathrm{kg})$ & $H_{\mathrm{ex}}$ & $H_{\text {in }}$ & $I_{\gamma}$ \\
\hline S1 & Bursa & $42.45 \pm 2.12$ & 0.05 & $91.60 \pm 4.58$ & 0.25 & 0.35 & 0.33 \\
\hline S2 & Bilecik & $30.95 \pm 1.55$ & 0.04 & $66.78 \pm 3.34$ & 0.18 & 0.25 & 0.24 \\
\hline S3 & Balıkesir & $40.27 \pm 2.01$ & 0.05 & $87.86 \pm 4.39$ & 0.24 & 0.33 & 0.31 \\
\hline S4 & Karaman & $51.84 \pm 2.59$ & 0.06 & $115.11 \pm 5.76$ & 0.31 & 0.44 & 0.40 \\
\hline S5 & Eskişehir & $30.13 \pm 1.51$ & 0.04 & $62.44 \pm 3.12$ & 0.17 & 0.25 & 0.23 \\
\hline S6 & Kayseri & $38.65 \pm 1.93$ & 0.05 & $84.48 \pm 4.22$ & 0.23 & 0.28 & 0.31 \\
\hline S7 & Diyarbakır & $31.55 \pm 1.58$ & 0.04 & $68.19 \pm 3.41$ & 0.18 & 0.26 & 0.25 \\
\hline S8 & Malatya & $47.98 \pm 2.40$ & 0.06 & $105.97 \pm 5.30$ & 0.29 & 0.41 & 0.37 \\
\hline S9 & Elazı̆̆ & $44.30 \pm 2.22$ & 0.05 & $98.02 \pm 4.90$ & 0.26 & 0.30 & 0.36 \\
\hline S10 & Isparta & $37.88 \pm 1.89$ & 0.05 & $82.36 \pm 4.12$ & 0.22 & 0.32 & 0.29 \\
\hline S11 & Burdur & $52.26 \pm 2.61$ & 0.06 & $113.14 \pm 5.66$ & 0.31 & 0.39 & 0.41 \\
\hline S12 & Hatay & $44.05 \pm 2.20$ & 0.05 & $96.87 \pm 4.84$ & 0.26 & 0.36 & 0.34 \\
\hline S13 & Afyon & $73.65 \pm 3.68$ & 0.09 & $159.95 \pm 8.00$ & 0.43 & 0.56 & 0.58 \\
\hline S14 & İzmir & $32.19 \pm 1.61$ & 0.04 & $70.42 \pm 3.52$ & 0.19 & 0.25 & 0.25 \\
\hline S15 & Manisa & $44.05 \pm 2.20$ & 0.05 & $96.87 \pm 4.84$ & 0.26 & 0.36 & 0.34 \\
\hline S16 & Denizli & $52.38 \pm 2.62$ & 0.06 & $114.43 \pm 5.72$ & 0.31 & 0.42 & 0.41 \\
\hline S17 & Kastamonu & $63.64 \pm 3.18$ & 0.08 & $137.92 \pm 6.90$ & 0.37 & 0.50 & 0.50 \\
\hline S18 & Karabük & $37.65 \pm 1.88$ & 0.05 & $82.83 \pm 4.14$ & 0.22 & 0.31 & 0.29 \\
\hline S19 & Amasya & $67.20 \pm 3.36$ & 0.08 & $146.01 \pm 7.30$ & 0.39 & 0.52 & 0.53 \\
\hline
\end{tabular}

and $31.92 \mathrm{~Bq} / \mathrm{kg}$, respectively. The mean activity concentrations are lower than the world mean values identified by UNSCEAR [11]. From the measured values, the average values of absorbed dose rate in air $(D)$, annual effective dose (AED), radium equivalent activity $\left(\mathrm{Ra}_{\mathrm{eq}}\right)$, external hazard index $\left(H_{\mathrm{ex}}\right)$, and internal hazard index $\left(H_{\mathrm{in}}\right)$ were calculated and these were $45.43 \mathrm{nGy} / \mathrm{h}, 0.056 \mathrm{mSv} / \mathrm{y}, 99.0 \mathrm{~Bq} / \mathrm{kg}, 0.27$, and 0.36 , respectively. All the calculated values are lower than the recommended maximum values in the UNSCEAR [11] reports. As a result of these, it can be concluded that for people who are using and mining sedimentary rock in these regions of Turkey are safe in terms of radiation hazards.

\section{Conflict of Interests}

The authors declare that there is no conflict of interests regarding the publication of this paper.

\section{Acknowledgments}

This work was supported by the Suleyman Demirel University Foundation Unit (BAP) with the Project no. of 2226-D-10. The authors wish to thank to Professor Dr. R. Altındag for helping in providing rocks samples.

\section{References}

[1] T. Santawamaitre, D. Malain, H. A. Al-Sulaiti, M. Matthews, D. A. Bradley, and P. H. Regan, "Study of natural radioactivity in riverbank soils along the Chao Phraya river basin in Thailand,"
Nuclear Instruments and Methods in Physics Research A, vol. 652, no. 1, pp. 920-924, 2011.

[2] A. Abbady, N. K. Ahmed, A. M. El-arabi, R. Michel, A. H. Elkamel, and A. G. E. Abbady, "Estimation of radiation hazard indices from natural radioactivity of some rocks," Nuclear Science and Techniques, vol. 17, no. 2, pp. 118-122, 2006.

[3] A. M. El-Arabi, N. K. Ahmed, and A. H. El-Kamel, "Gamma spectroscopic analysis of powdered granite samples in some Eastern desert's areas," in Proceedings of the 5th Radiation Conference, Cairo, Egypt, November 2000.

[4] A. I. Abd El-mageed, A. H. El-Kamel, A. Abbady, S. Harb, A. M. M. Youssef, and I. I. Saleh, "Assessment of natural and anthropogenic radioactivity levels in rocks and soils in the environments of Juban town in Yemen," Radiation Physics and Chemistry, vol. 80, no. 6, pp. 710-715, 2011.

[5] I. Akkurt, B. Oruncak, and K. Gunoglu, "Natural radioactivity and dose rates in commerciallyused marble from Afyonkarahisar-Turkey," International Journal of Physical Sciences, vol. 5, no. 2, pp. 170-173, 2010.

[6] I. Akkurt, M. B. Mavi, H. A. H. Akyildirim, and K. G. K. Günoglu, "Natural radioactivity of coals and its risk assessment," International Journal of Physical Sciences, vol. 4, no. 7, pp. 403406, 2009.

[7] I. Akkurt, K. Gunoglu, and Ş.Ş. Arda, "Detection efficiency of $\mathrm{NaI}(\mathrm{Tl})$ detector in 511-1332 keV," Science and Technology of Nuclear Installations. In press.

[8] D. Amrani and M. Tahtat, "Natural radioactivity in Algerian building materials," Applied Radiation and Isotopes, vol. 54, no. 4, pp. 687-689, 2001.

[9] F. Steger and K. Grün, A Standard in AUSTRIA to Limit Natural Radioactivity in Building Materials, IAEA, Vienna, Austria, 1999. 
[10] UNSCEAR, United Nations Scientific Committee on the Effects of Atomic Radiation. Annex A: Exposure from Natural Sources, United Nations, New York, NY, USA, 1993.

[11] UNSCEAR, United Nations Scientific Committee on the Effects of Atomic Radiation. Annex A: Exposure from Natural Sources, United Nations, New York, NY, USA, 2000.

[12] U. Cevik, N. Damla, A. I. Kobya, A. Celik, and A. Kara, "Radiation dose estimation and mass attenuation coefficients of marble used in Turkey," Annals of Nuclear Energy, vol. 37, no. 12, pp. 1705-1711, 2010.

[13] R. Veiga, N. Sanches, R. M. Anjos et al., "Measurement of natural radioactivity in Brazilian beach sands," Radiation Measurements, vol. 41, pp. 189-196, 2006.

[14] J. Beretka and P. J. Mathew, "Natural radioactivity of Australian building materials, industrial wastes and by-products," Health Physics, vol. 48, no. 1, pp. 87-95, 1985. 


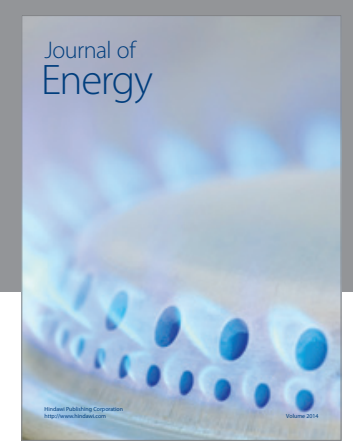

Journal of

Industrial Engineering
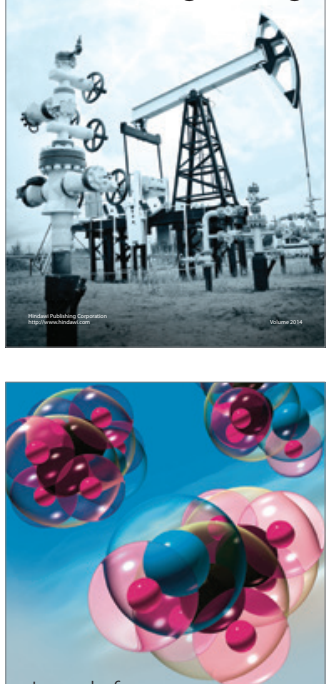

Fuels
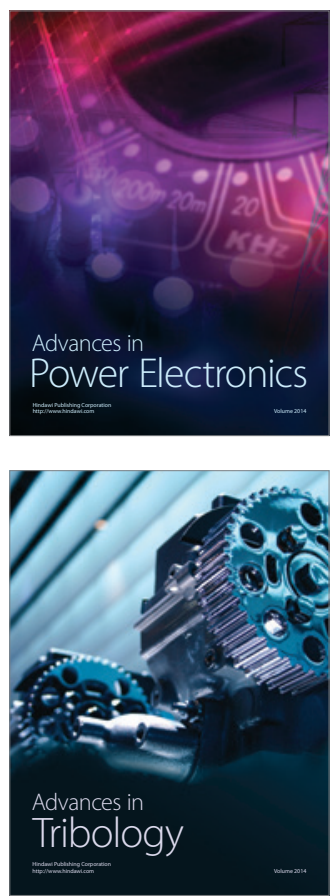

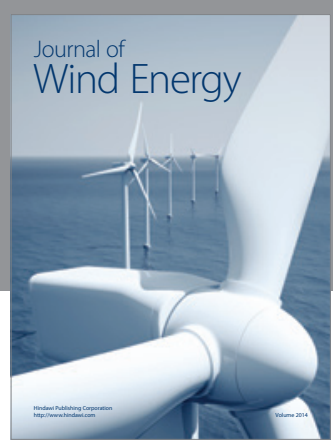

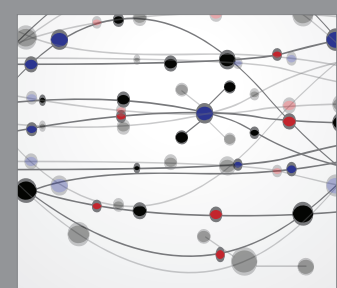

The Scientific World Journal

Submit your manuscripts at http://www.hindawi.com

Journal of

Structures
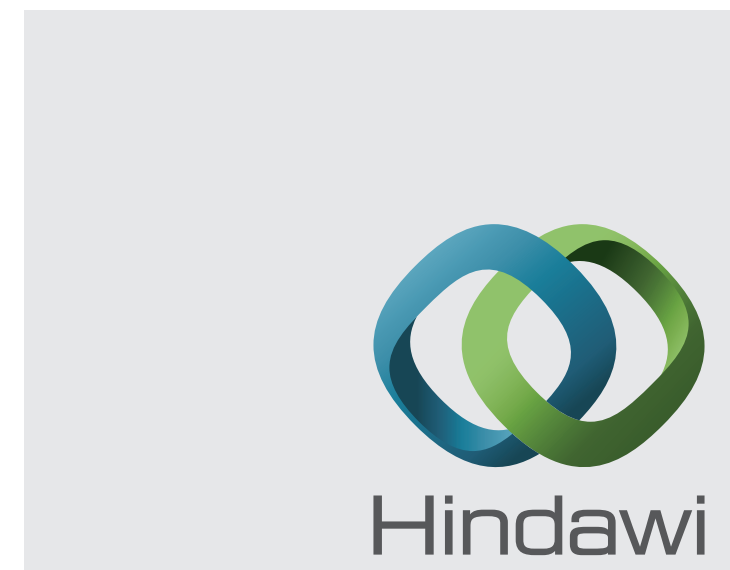

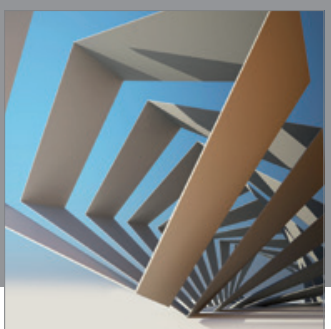

Rotating

Machinery
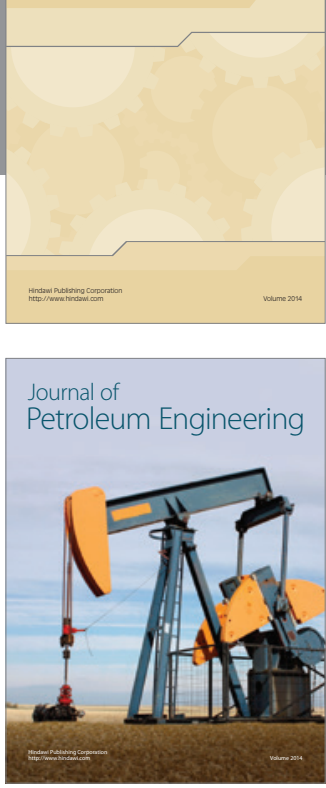

Journal of

Solar Energy
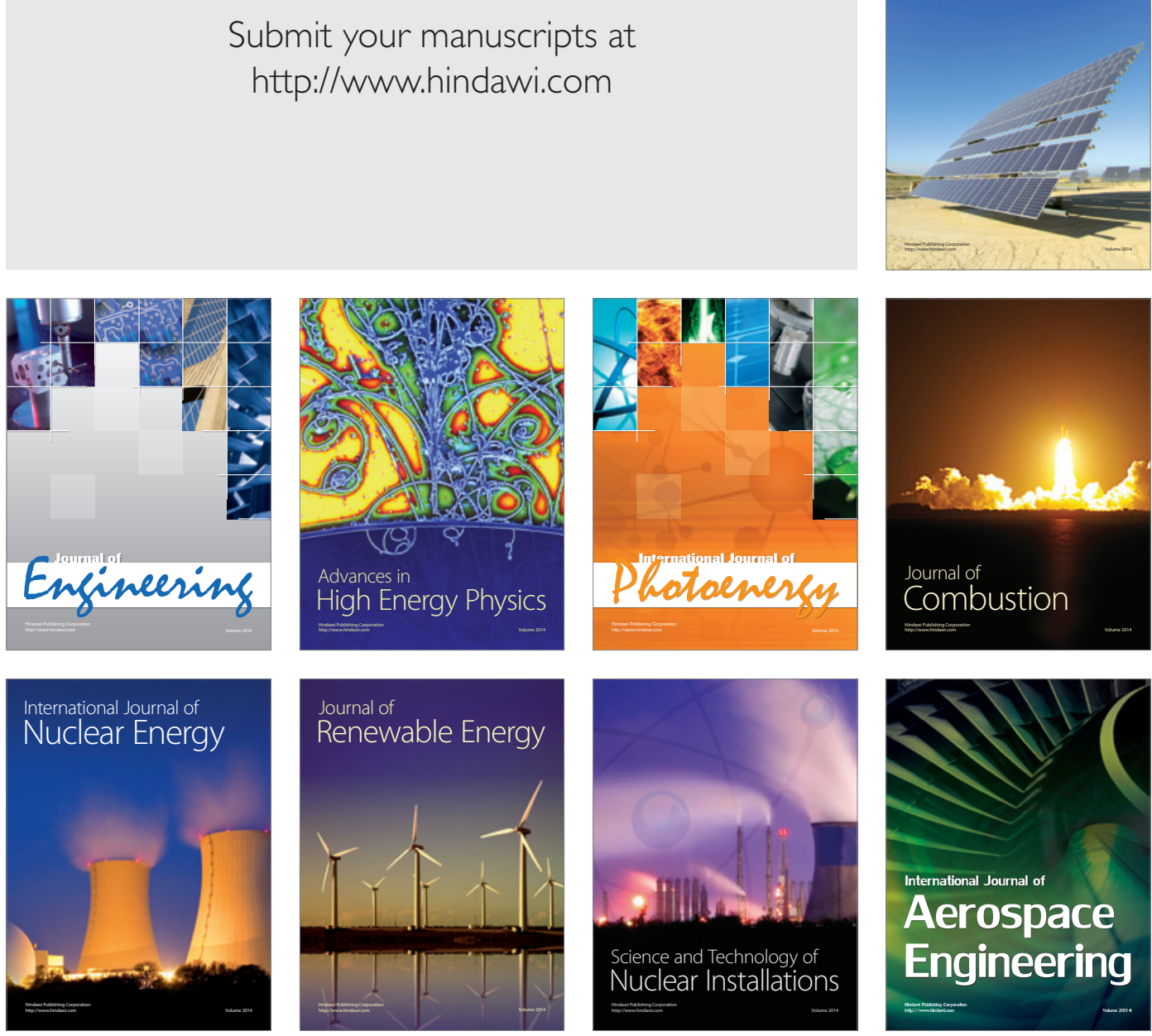